\title{
PEMBERDAYAAN TEKNOLOGI INFORMASI UNTUK KEUNGGULAN BISNIS
}

\author{
Oleh: Supriyanto \\ (Staf Pengajar di Fakultas I/mu Sosial Universitas Negeri Yogyakarta)
}

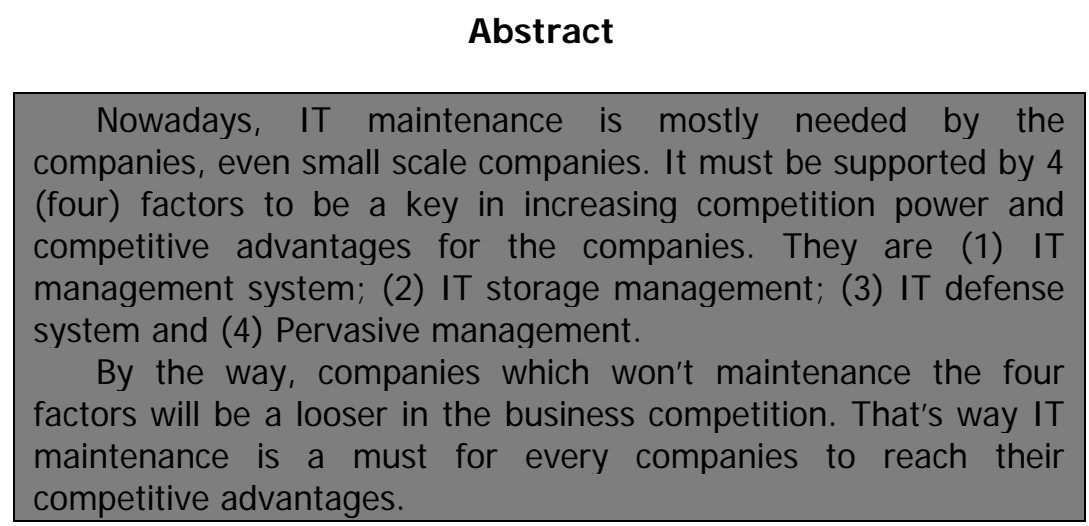

Key Words: Information Technology, Competitive Advantage

\section{A. Pendahuluan}

Dalam era perdagangan bebas seperti saat sekarang ini, masalah daya saing dan keunggulan saing merupakan isu kunci dan sekaligus sebagai tantangan yang tidak ringan bagi bangsa dan rakyat Indonesia. Salah satu ujud konkret tantangan globalisasi dalam produksi misalnya kita dituntut agar produk Indonesia mampu bersaing terhadap produk luar yang masuk ke Indonesia. Ataupun di pasar internasional produksi kita didefinisikan (bukan penyedia barang murah bersubsidi) tidak saja akan membuat murah produk yang dihasilkan tetapi juga akan membangun produk Indonesia yang mempunyai keunggulan kompetitif (competitive advantages).

Dalam pasar dunia yang semakin terbuka, masalah daya saing akan menghadapi tantangan yang tidak ringan, maka tanpa dibekali kemampuan dan keunggulan saing yang tinggi niscaya produk suatu negara, termasuk produk Indonesia, tidak akan mampu menembus pasar internasional. Bahkan masuknya produk impor dapat mengancam posisi pasar domestik. Dengan kata lain, dalam pasar yang bersaing, keunggulan kompetitif (competitive advantages) merupakan faktor penentu dalam meningkatkan kinerja perusahaan. Oleh karena itu, upaya meningkatkan daya saing dan membangun keunggulan kompetitif bagi produk Indonesia tidak dapat ditundatunda lagi dan sudah selayaknya menjadi perhatian berbagai kalangan, bukan saja bagi para pelaku bisnis itu sendiri tetapi juga bagi aparat birokrasi, berbagai organisasi dan anggota masyarakat yang merupakan lingkungan kerja dari kegiatan bisnis korporasi (bisnis corporate). 
Globalisasi ekonomi di awal abad 21 merupakan suatu proses kegiatan ekonomi dan perdagangan, di mana negara-negara di seluruh dunia menjadi satu kekuatan pasar yang semakin terintegrasi dengan tanpa rintangan batas teritorial negara. Perwujudan nyata dari globalisasi ekonomi antara lain terjadi dalam bentuk-bentuk berikut: Globalisasi produksi, di mana perusahaan berproduksi di berbagai negara, dengan sasaran agar biaya produksi menjadi lebih rendah. Globalisasi pembiayaan, perusahaan global mempunyai akses untuk memperoleh pinjaman atau melakukan investasi (baik dalam bentuk portofolio ataupun langsung) di semua negara di dunia. Globalisasi tenaga kerja, maka human movement akan semakin mudah dan bebas. Globalisasi jaringan informasi, masyarakat suatu negara dengan mudah dan cepat mendapatkan informasi dari negara-negara di dunia karena kemajuan teknologi. Globalisasi perdagangan, terwujud dalam bentuk penurunan dan penyeragaman tarif serta penghapusan berbagai hambatan nontarif. Dengan demikian kegiatan perdagangan dan persaingan menjadi semakin ketat dan fair. Bahkan, transaksi menjadi semakin cepat karena "less papers/documents" dalam perdagangan, tetapi dapat mempergunakan jaringan teknologi telekomunikasi yang semakin canggih.

Pada kegiatan bisnis korporasi (bisnis corporate) di atas dapat dikatakan bahwa globalisasi mengarah pada meningkatnya ketergantungan ekonomi antarnegara melalui peningkatan volume dan keragaman transaksi antarnegara (cross-border transactions) dalam bentuk barang dan jasa, aliran dana internasional (international capital flows), pergerakan tenaga kerja (human movement) dan penyebaran teknologi informasi yang cepat. Sehingga secara sederhana dapat dikemukakan bahwa globalisasi secara hampir pasti telah merupakan salah satu kekuatan yang memberikan pengaruh terhadap bangsa, masyarakat, kehidupan manusia, lingkungan kerja dan kegiatan bisnis corporate di Indonesia. Kekuatan ekonomi global menyebabkan bisnis korporasi, termasuk swasta, BUMN/BUMD ataupun koperasi, perlu melakukan tinjauan ulang terhadap struktur dan strategi usaha serta melandaskan strategi manajemennya dengan basis entrepreneurship, cost efficiency dan competitive advantages.

Salah satu upaya menciptakan keunggulan bersaing dalam situasi pasar bisnis yang sangat dinamis seperti sekarang ini adalah melakukan pendayagunaan teknologi informasi. Pendayagunaan teknologi informasi (TI) memegang peranan yang sangat penting dalam menjamin kelancaran dan optimisasi layanan ke pelanggan serta meningkatkan kinerja suatu perusahaan. Ada sejumlah faktor penting yang mempengaruhi pentingnya peranan pendayagunaan $\mathrm{TI}$ dalam suatu perusahaan, seperti meningkatnya popularitas web, pertumbuhan komputasi pervasive, serta hadirnya model bisnis baru. Akibatnya, kini perusahaan mempunyai kesempatan lebih luas di sisi penawaran dan layanan bagi pelanggannya. Dan, makin besarnya peluang yang dimiliki setiap perusahaan, tentu membuat tantangannya semakin berat. Oleh sebab itu, perusahaan membutuhkan model bisnis yang tepat 
dan solusi manajemen teknologi yang bisa mendayagunakan semua aset teknologi secara baik dan membantu perusahaan secara cepat dalam menjawab kebutuhan bisnis dan pasar yang terus berkembang.

Tulisan singkat ini mencoba mengungkap pendayagunaan teknologi informasi untuk mencapai keunggulan bisnis perusahaan.

\section{B. Teknologi I nformasi sebagai Aplikasi I ptek}

Ilmu pengetahuan dan teknologi (Iptek), saat ini merupakan kata kunci bagi keberhasilan pembangunan suatu bangsa maupun suatu perusahaan. Perjalanan sejarah serta pengalaman beberapa negara, ternyata inovasi teknologi merupakan salah satu aspek yang memiliki daya dongkrak (leverage) yang sangat tinggi bagi daya saing suatu bangsa. Hal ini menunjukkan adanya pergeseran yang besar dalam paradigma pembangunan suatu negara, yang semula hanya mengandalkan sumber daya alam sebagai tumpuan pembangunan, berubah menjadi sumber daya manusia dan sumber daya iptek. Beberapa negara maju bahkan sudah lama menjadikan iptek sebagai penghela utama dalam pembangunan bangsanya. Konsep "knowledge base economy" (KBE atau ekonomi berbasis pengetahuan/EBP) merupakan konsep yang mencerminkan kondisi tersebut. Saat ini konsep EBP banyak dikembangkan di negara-negara maju, yang pada intinya menekankan betapa sangat berperannya teknologi dan informasi dalam pembangunan suatu bangsa.
Pada dasarnya salah satu kunci keberhasilan suatu bangsa menerapkan inovasi teknologi dalam pembangunannya adalah adanya dukungan sistem kelembagaan inovasidifusi yang sudah mapan. Antar satu lembaga dengan lembaga lainnya saling bersinergi, sehingga tercipta jejaring kerjasama yang saling mengisi untuk menghasilkan inovasi yang benar-benar mampu meningkatkan daya saing bangsa dalam persaingan global.

Dalam pada itu, untuk mengantisipasi persaingan antar bangsa yang semakin ketat, secara legal formal Bangsa Indonesia telah memiliki landasan kuat untuk mendayagunakan I ptek dalam kehidupan berbangsa, yakni Pasal 31 Ayat 5 UUD 45 hasil Amandemen ke 4. Lebih jauh lagi, sejak tahun 2002 Indonesia telah memiliki UU No 18 tahun 2002 mengenai Sistem Nasional Penelitian, Pengembangan, dan Penerapan I ptek (Sinasiptek).

Tujuan dari pembuatan UU tersebut adalah untuk memperkuat daya dukung iptek bagi keperluan mempercepat pencapaian tujuan negara serta meningkatkan daya saing dan kemandirian dalam pergaulan antar bangsa. Kelembagaan dan jejaring kerja antar lembaga iptek merupakan aspek yang diatur dalam undang-undang tersebut.

Dalam UU no 18 tahun 2002, kelembagaan iptek terdiri atas unsur perguruan tinggi, lembaga litbang, badan usaha, dan lembaga penunjang. Lembaga litbang sebagai salah satu unsur kelembagaan dalam Sinasiptek berfungsi menumbuhkan kemampuan pemajuan iptek. Lembaga litbang bertanggung jawab mencari berbagai 
penemuan (invention) di bidang iptek serta menggali potensi pendayagunannya. Lembaga litbang dapat berupa organisasi yang berdiri sendiri, atau bagian dari organisasi pemerintah, pemerintah daerah, perguruan tinggi, badan usaha, lembaga penunjang, dan organisasi masyarakat. Untuk memadukan sinergisme kerja berbagai unsur kelembagaan iptek, Undang-undang tersebut menjelaskan mengenai jaringan Sinasiptek. Jaringan tersebut berfungsi untuk membentuk jalinan hubungan interaktif yang memadukan unsur-unsur kelembagaan iptek dalam menghasilkan kinerja dan manfaat lebih besar dibandingkan apabila masing-masing unsur kelembagaan berjalan secara sendiri-sendiri. Untuk mengembangkan jaringan tersebut seluruh elemen Sinasiptek wajib mengusahakan kemitraan dalam hubungan yang saling mengisi, melengkapi, memperkuat, dan menghindarkan terjadinya tumpang tindih yang merupakan pemborosan.

Dalam suatu perusahaan salah satu tantangan yang lazim dihadapi perusahaan dalam pengelolaan teknologi adalah kurangnya sumber daya. Banyak perusahaan harus mengelola sistem TI dengan keterampilan, sumber daya, dan anggaran yang terbatas. Terbatasnya jumlah sumber daya manusia (SDM) dan tingginya tingkat turn-over SDM membuat perusahaan kewalahan dalam mengantisipasi kebutuhan pasar dengan kemajuan teknologi yang begitu dinamis. Solusi manajemen yang tepat diperlukan tidak hanya untuk mengelola sumber daya $\mathrm{TI}$, tapi juga harus memberikan informasi yang mudah dipahami dan digunakan dalam lingkungan multiplatform. Dengan demikian, keterampilan sumber daya manusia dapat dioptimalkan untuk melakukan pemikiran analitis dan strategis yang tujuan akhirnya adalah meningkatkan kinerja perusahaan. Sebagai contoh, sebuah solusi manajemen yang baik bisa menunjukkan titik-titik lemah dalam sebuah jaringan komputer, misalnya komputer yang berkinerja rendah. Dengan kemampuan ini, pengguna tak perlu memeriksa/menguji secara manual, satu-per-satu, setiap komponen jaringannya.

\section{E-Business dan E-Commerce Bentuk Optimisasi Layanan ke Pelanggan}

Salah satu bentuk pendayagunaan teknologi informasi untuk keunggulan bersaing adalah perwujudan pemanfaatan keunggulan teknologi informasi untuk pelayanan ke pelanggan. Dalam kaitannya dengan pelanggan, solusi manajemen $\mathrm{Tl}$ akan menjamin optimisasi (kondisi terbaik) layanan bisnis ke pelanggan. Bentuk solusi manajemen ini harus menyediakan perangkat yang efektif dan terintegrasi untuk mengelola infrastruktur teknologi. Di samping memiliki infrastruktur yang reliabel, solusi manajemen $\mathrm{TI}$ juga harus bisa membantu perusahaan mengimplementasikan pendekatan inovatif terhadap bisnis dan memanfaatkan aset teknologi untuk meningkatkan kinerja melalui pilihan aplikasi bisnis strategis yang luas.

Bentuk konkret aplikasi teknologi informasi dalam bisnis yang akhir-akhir ini banyak ditulis dan dibahas mengenai e-business baik di media cetak maupun elektronik, sebut saja Fortune, The 
Economist, Asian Business. Kalau beberapa waktu yang lalu Amerika dan negara-negara di Eropa demam internet, kini gilirannya di Asia, bahkan Indonesia. Internet telah menjadi bagian dari gaya hidup baru. Gelombang informasi yang dapat diakses dengan media ini berpengaruh besar dalam semua bidang, termasuk bidang ekonomi dan bisnis. Bahkan bidang ini terdapat kehadiran berbagai istilah baru sebut saja, $e$ commerce, e-business, e-PR, emarketing dan lain-lain.

Pengertian dari beberapa istilah antara lain : Electronic Commerce (Perniagaan Elektronik), sebagai bagian dari Electronic Business (bisnis yang dilakukan dengan menggunakan electronic transmission), oleh para ahli dan pelaku bisnis dicoba dirumuskan definisinya dari terminologi E-Commerce (Perniagaan Elektronik). Secara umum e-commerce dapat didefinisikan sebagai segala bentuk transaksi perdagangan/perniagaan barang atau jasa (trade of goods and service) dengan menggunakan media elektronik. Jelas, selain dari yang telah disebutkan di atas, bahwa kegiatan perniagaan tersebut merupakan bagian dari kegiatan bisnis. Kesimpulan: "e-commerce is a part of e-business". E-PR (Electronic Public Relations) atau humas melalui elektronik merupakan bagian dari $E$ Marketing (Pemasaran Elektronik), sebab E-Marketing membawahi semua jenis komunikasi pemasaran online. E-PR adalah penerapan dari perangkat ICT (Information and Communication Technologies) untuk keperluan public relations. Praktisi E-PR harus seorang yang handal dalam berselancar di dunia maya dan tahu ke mana saja mereka harus berselancar untuk membangun brand. E-PR adalah satu-satunya cara untuk membangun brand di dunia yang tidak kasat yaitu dunia maya mengingat internet telah menghadirkan dunia maya di samping dunia nyata.

Internet banyak disadari para perilaku bisnis sebagai salah satu tool (alat) untuk mengembangkan bisnis di masa depan. Bahkan Indonesia diproyeksikan sebagai salah satu kawasan e-business utama di kawasan Asia untuk masa mendatang. Banyak konglomerat Indonesia yang memilih untuk terjun ke dunia e-business, seperti Eka Tjipta, James Riady, Peter Gonta, Grup Bakrie dan masih ada yang lainnya. Nah, bagaimana menurut penuturan para pakar dan pimpinan perusahaan mengenai e-business tersebut?

Para pakar berbagi pengalaman dan kegunaan e-business yang dibahas dari berbagai segi. Berbagai situs internet yang kian hari makin semarak merupakan salah satu modal untuk terjun ke e-business. Sebab dengan adanya e-business orang dapat bertransaksi langsung dengan jangkauan global. Selain peluang pertumbuhan yang dicapai perusahaan menjadi lebih besar, perusahaan berarti melakukan lompatan jauh ke depan berbisnis tanpa batas wilayah. Di samping itu, e-business memungkinkan para perusahaan menjalin kerjasama dengan berbagai perusahaan di seluruh dunia dan dapat secara langsung dengan buyer melalui cara yang lebih cepat dan efisien serta hemat biaya.

Menurut Paulus Bambang, Direktur AGIT, terjun ke e-business merupakan konsekuensi logis kondisi masa depan. Lain halnya dengan Dicky Iskandar Di 
Nata (Business.htm), Presdir Jaring Data Informasi (JDI), ia cenderung mengungkap data mengenai para pengguna Internet yang tentunya akan menjadi pangsa pasar yang berkaitan dengan e-business itu sendiri. Menurutnya kini terdapat 176.000 pelanggan perorangan, 4200 perusahaan dan diperkirakan terdapat 850.000 - 1 juta pengguna Internet. Para pengguna internet pada umumnya terkonsentrasi di Jabotabek yang jumlahnya sekitar $50 \%$, selebihnya di 5 kota besar di Indonesia. Sedangkan akses Internet kebanyakan dilakukan dari kantor, diperkirakan mencapai $50 \%$ dan selebihnya dilakukan dari rumah dan warnet. Lebih rinci ia menyebutkan terdapat sekitar $37 \%$ pengguna internet tidak pernah melakukan transaksi, oleh sebab tidak memiliki kartu kredit, selebihnya karena masalah security. Ia juga menambahkan bahwa e-business pada umumnya masih dalam tahap awal development. Untuk memperoleh keuntungan maksimal, tentunya dengan adanya Internet akan menjadi nilai tambah yang cukup berarti bagi dunia usaha di tanah air. Karena Internet merupakan platform komunikasi dengan laju pertumbuhan yang paling tinggi sejak ditemukannya telepon. Internet menciptakan beragam tingkat komunikasi secara elektronik antar institusi/organisasi tanpa batas. Internet merupakan "low cost delivery mechanism" untuk content maupun software.

Hal lain yang diperkirakan akan tumbuh subur adalah Application Service Provider (ASP), yang merupakan komponen penting dari "jaringan ekonomi baru" ini, yaitu sebagai fasilitator mutasi proses bisnis di dalam internet (Extended Enterprise). Perkembangan Web Based Software memungkinkan distribusi serta management penggunaan aplikasi kepada multiple users dari data center melalui "wide area network". Ada beberapa alasan kenapa ASP akan tumbuh subur?. Pertama, karena biaya investasi packaged software yang tinggi bagi skala usaha kecil dan menengah di Indonesia. Kedua, keterbatasan Sumber Daya Manusia dalam bidang TI untuk implementasi dan pemeliharaan aplikasi serta software. Ketiga, karena tingginya biaya investasi untuk membangun infrastruktur IT dan maintenance.

Pemanfaatan lain yang juga cukup menonjol pada ASP Internet Banking, khususnya industri perbankan. Tanpa dukungan ASP internet banking sistem pembayaran dan settlement yang memadai maka e-business tidak akan berkembang bahkan lebih banyak keraguan. Apa manfaat perbankan menggunakan ASP ?. Entry ke dunia e-business bagi perbankan nasional, memperkecil biaya intermediasi, sarana marketing, pergeseran dari traditional branch banking (yang relatif mahal) ke future net banking, dan menghantarkan servis perbankan tak terbatas di mana nasabah berada.

Sementara itu, AB Susanto, Direktur JCG antara lain mengungkapkan tujuh prinsip dalam e-business, yakni harus ada saling pengertian di antara para customer, perusahaan harus memandang bahwa dengan menggunakan internet akan mendatangkan keuntungan yang lebih banyak, para pemegang jabatan di perusahaan menyukai kepastian keuntungan yang berasal dari e-business, 
para pemegang jabatan di perusahaan dapat memanfaatkan kesempatan yang terbuka, perusahaan dan pemegang jabatan di perusahaan berani menciptakan hal-hal yang mendatangkan keuntungan, perusahaan harus mengantisipasi dan lebih proaktif agar tetap eksis dan sigap terhadap para pesaing baru, dan tidak hanya menguntungkan programnya saja. Selain itu, diperlukan faktor pendukung dalam menciptakan strategi e-business, yaitu membangun sebuah strategi team $e$ business yang efektif, menentukan keperluan customer, menganalisis arus dan potensial pesaing yang strategis, melakukan studi dan identifikasi terhadap nilai tambah customer, merevisi dan mengevaluasi strategi e-business setiap waktu, melakukan seleksi strategi secara optimal, dan mengimplementasikan halhal tersebut dalam tindakan nyata.

$$
\text { Untuk membuat perusahaan }
$$

mampu memanfaatkan sepenuhnya potensi e-business dan meraih keuntungan dari e-business, solusi yang digunakan juga harus menyediakan perangkat untuk meningkatkan keamanan, reliabilitas, dan ketersediaan aplikasi e-commerce dan sistem yang mendasarinya seperti customer relationship management (CRM) dan supply chain management (SCM).

\section{Kriteria Penerapan E-Business dalam Perusahaan}

Salah satu alasan perusahaan menerapkan e-business adalah efisiensi. Kriteria penilaian efisiensi dapat didasarkan pada analisis internal perusahaan untuk melihat penerapan $e$ business terhadap kemampuan perusahaan meningkatkan revenue dan menurunkan biaya operasional. Adapun kriteria seberapa jauh perusahaan telah menerapkan e-business dilihat dari beberapa indikator dan setelah diperoleh data maka perlu dilakukan penilaian dengan melakukan pembobotan dari beberapa indikator yang ada. Beberapa kriteria yang ditetapkan adalah sebagai berikut:

\section{Customer Value}

Yang dimaksud customer value adalah nilai-nilai yang diterima oleh konsumen dilihat dari semua aspek nilai-nilai perusahaan yang melekat dalam produk dan atau jasa yang diberikan kepada konsumen. Pemahaman ini didasarkan juga pada pengertian yang disebutkan oleh Phillip Kotler (1999) yang menyatakan, 'Total customer value is the bundle of benefits customer expect from a given product or service.'

Nilai-nilai yang diterima konsumen adalah berbagai benefit dalam bentuk sebagai berikut:
a. Product Value: Konsumen memperoleh produk yang berkualitas sesuai dengan yang diharapkan.
b. Service Value: Konsumen memperoleh jasa yang berkualitas sesuai dengan yang diharapkan.

c. Personnel Value: Konsumen memperoleh layanan yang memuaskan dari karyawan perusahaan.

d. Image Value: Citra perusahaan yang menjadi bahan pertimbangan customer dalam menentukan suatu pembelian produk/jasa. 


\section{Proses Efisiensi}

Melihat proses efisiensi suatu perusahaan dalam berbagai bidang industri akan sangat bervariasi. Proses efisiensi sendiri didefinisikan sebagai kemampuan perusahaan untuk mengoptimalisasi rasio input terhadap output. Pendekatan umum yang bisa digunakan untuk menilai efisiensi adalah dengan melihat kinerja keuangan. Proses efisiensi suatu perusahaan dapat dilihat berdasarkan rasio antara sales dan total jumlah karyawan. Rasio ini setidaknya menggambarkan efisiensi secara umum di perusahaan, meskipun belum memberikan gambaran secara khusus efisiensi secara mendetail.

3. I novasi

Inovasi dalam bidang teknologi informasi di perusahaan dinilai berdasarkan jenis dan frekuensi penerapan ide atau gagasan baru dalam proses bisnis maupun yang berhubungan langsung dengan produk atau jasa yang diberikan. Inovasi ini ditentukan dalam hitungan satu tahun terakhir.

\section{Human Resources}

Sumber daya manusia dalam konteks penilaian pelaksanaan $e$ business di suatu perusahaan adalah sumber daya manusia dalam perusahaan yang dapat menunjang dan mendukung strategi perusahaan dalam menerapkan e-business. Beberapa hal yang dinilai adalah:
a. Persentase karyawan yang memiliki kemampuan menggunakan komputer terhadap total jumlah karyawan.
b. Banyaknya pelatihan untuk meningkatkan kemampuan karyawan dalam bidang teknologi informasi yang diberikan perusahaan dalam jangka waktu satu tahun.
c. Persyaratan minimum kemampuan/keahlian dalam bidang teknologi informasi bagi karyawan yang akan masuk perusahaan.

\section{Komitmen manajemen terhadap pengembangan teknologi informasi}

Komitmen ini bisa dilihat dari jumlah investasi yang ditanamkan untuk pengembangan e-business di perusahaan. Komitmen manajemen dalam penilaian ini diartikan sebagai besarnya perhatian manajemen perusahaan terhadap penerapan $e$ business perusahaan dilihat dari besarnya investasi dalam bidang teknologi informasi.

\section{Penggunaan Internet}

Tingkat penggunaan internet untuk menunjang implementasi $e$ business di perusahaan juga merupakan salah satu indikator pelaksanaan e-business. Pendekatan ini dilakukan dengan melihat:
a. Perbandingan penggunaan
personal address dengan domain
perusahaan terhadap total
jumlah karyawan.
b. Tersedianya situs perusahaan.
c. Tersedianya transaksi bisnis melalui internet.

Beberapa contoh perusahaan yang sudah sangat maju dalam aplikasi teknologi informasi di Indonesia dan perusahaan-perusahaan tersebut termasuk unggul dalam penerapan 
teknologi informasi dan performance perusahaan tersebut juga cukup baik dan sebagai pemenang E-Company Award 2002 (Sumber : Warta Ekonomi, 30 Oktober 2002) :

\section{Kategori Retail: PT Matahari Putra Prima Tbk.}

Perombakan struktur bisnis dan manajemen dilakukan Lippo untuk memperbaiki kinerja usaha PT Matahari Putra Prima Tbk. Lewat implementasi e-commerce $B 2 B$ (Business to Business), perusahaan dengan 77 department store dan 64 supermarket ini berharap bisa menuju bisnis yang lebih efisien. . Untuk itu, perombakan pun dilakukan dalam hubungan peritel ini dengan para pemasoknya. Caranya, dengan meningkatkan kinerja implementasi sistem e-commerce B2B (business to business) yang sudah go live sejak tahun 1999 lalu. Saat ini, Matahari tercatat sudah berhubungan secara elektronis dengan pemasok besarnya seperti Martha Tilaar, Mustika Ratu, dan Nestle. Lewat sebuah gateway yang didirikan oleh PT I ndosatcom Adimarga, berbagai sistem dari pemasok diintegrasikan dalam sebuah jaringan. Yang diatur adalah alur informasi dari pemasok ke Matahari dalam kaitan dengan pengadaan barang yang dibutuhkan oleh konsumen. Yang jelas, saat ini, dengan bergabung kepada gateway Indosatcom, para pemasok Matahari bisa memangkas biaya administrasi pengadaan barang sebesar $50 \%$. Angka ini berasal dari berkurangnya biaya pengiriman faks, pengarsipan, dan entry data. Jelasnya, kalau sebelumnya biaya pengurusan per dokumen mencapai Rp5.694, maka sesudah e-commerce B2B diterapkan, ongkosnya cuma Rp2.854 per dokumen.

2. Kategori Manufacturing: PT Unilever I ndonesia Tbk.

Untuk mempertahankan dominasinya di pasar consumer goods, PT Unilever Indonesia Tbk. mengandalkan kemampuannya melakukan inovasi. Untuk menaikkan laba, Unilever memutuskan memanfaatkan jaringan internet dalam memperoleh pasokan bahan baku.

Hadir di Indonesia sejak tahun 1933, dominasi produk-produk PT Unilever Indonesia Tbk. di pasar consumer goods kian sulit tergoyahkan oleh para kompetitornya. Bahkan cengkeraman bisnis Unilever justru makin kuat dan kian menggurita. Unilever kini sudah menghasilkan 400 macam produk dan hampir seluruhnya merupakan produk-produk pemimpin pasar. Sulit rasanya menjumpai orang yang tak mengenal produk Unilever, mulai dari deterjen bubuk Rinso, pasta gigi Pepsodent, sampo Sunsilk, sabun Lux, hingga margarin Blue Band.

Bahkan terakhir Unilever berupaya menggandeng Texchem Resources Berhad Malaysia untuk mendirikan perusahaan patungan bernama PT Technopia Lever. Perusahaan ini nantinya akan bergerak di bidang pengembangan dan distribusi produk kesehatan, seperti obat nyamuk bakar, pembasmi serangga, dan oil spray. Bagi kantor pusat Unilever yang berada di Belanda, anak usahanya 
yang berada di Indonesia ini memang terhitung sebagai penyumbang pendapatan Unilever yang besar.

3. Kategori Telecommunication: PT Telkom Seluler (Telkomsel)

Dalam rangka memberikan kepuasan Pelanggan Berbasis TI, ekspansi dan inovasi yang terusmenerus dilakukan menjadi kunci keberhasilan Telkomsel untuk menjadi perusahaan operator nomor satu di Indonesia. Tidak puas hanya menjadi jago kandang di negeri sendiri, maka Tekomsel pun berambisi menjadi yang terbaik di kawasan Asia.

Menjadi perusahaan operator seluler yang terbaik di Asia adalah salah satu misi yang diemban oleh Telkomsel. Misi itu pulalah yang menjadikan perusahaan yang berdiri pada 26 Mei 1995 ini makin getoll untuk terus meningkatkan kualitas layanan, infrastruktur, serta teknologi yang dimilikinya. Komitmen mengenai pemberian layanan yang prima ini tampaknya terpancar dari para pucuk pimpinan Telkomsel yang dengan 'legowo' berjanji akan menerima masukan berupa keluhan atau usulan dari para konsumennya. 'Selain bersifat terbuka, hal lain yang tidak kalah pentingnya adalah bagaimana agar kami bisa menerjemahkan keinginan dan kebutuhan pelanggan.

Demi kepuasan pelanggan pulalah maka Telkomsel tak hentihentinya berinovasi menciptakan layanan-layanan baru. Di antaranya, customer care by online (caroline), billing and customer care system (bianca), supervision network performance (superman), dan aneka informasi tagihan (anita). Meskipun layanan yang ditawarkan kelihatannya sederhana, tetapi hal itu membutuhkan kemampuan dan kesiapan sistem teknologi informasi (TI) yang kuat.

\section{Kategori Transportation \& Distribution: PT Birotika Semesta (DHL)}

Lebih $50 \%$ dari total pengiriman DHL Indonesia dilakukan dengan cara otomatis. Dengan bekal sebuah scanner genggam, para kurir DHL membantu pelanggan melacak perjalanan kirimannya. Ini bagian paling nyata dari proses $\mathrm{DHL}$ memasuki ranah e-commerce.

Scanner dan bukan pistol. Itulah 'senjata genggam' paling mutakhir yang wajib dimiliki oleh ujung tombak dari perusahaan pengiriman barang seperti PT Birotika Semesta (DHL). Di perusahaan ini, sebuah scanner yang digenggam oleh petugas/kurir DHL menjadi titik awal perjalanan sebuah paket kiriman, sekaligus membuat paket tersebut berada dalam jangkauan pemantauan pengirimnya.

Setiap sorotan scanner yang dilakukan petugas/kurir DHL pada tahap demi tahap pengiriman adalah informasi berharga bagi pengirimnya. Di dalam scanner itu data dihimpun dan masuk ke back end system DHL dan terus ke sistem besar (service center). Dengan informasi inilah mereka bisa menandai lokasi paket kirimannya. 


\section{Kategori Finance: Bank Central Asia Tbk.}

Sebuah bank yang bersandarkan diri pada TI. Strategi BCA terus menciptakan delivery channel dengan $\mathrm{TI}$ yang memegang peranan penting boleh dikatakan sukses. Ia boleh dibilang berhasil tetap menjadi bank swasta ritel terbesar di Indonesia.

Pada 21 Februari 1957, di pusat perniagaan Jakarta berdirilah sebuah bank bernama Bank Central Asia NV. Dalam perjalanan sejarahnya, Bank Central Asia (BCA) yang kemudian menjadi sebuah bank publik ini terus mengalami pertumbuhan yang luar biasa. Anggapan ini bisa dikatakan tidaklah berlebihan ketika BCA berhasil membuktikannya melalui peningkatan total asetnya yang mencapai Rp53,36 triliun pada akhir 1997. Angka ini meningkat hampir 50\% dari total aset di tahun 1996. Walaupun pada tahun 1998 total aset BCA sempat turun ketika kejadian rush nasabah menderanya, tetapi hingga Juli 2002, nilai aset BCA terus membengkak menjadi Rp104,229 triliun. Saat ini selain sudah berhasil membangun jaringan ATM terbesar di Indonesia, BCA kini juga berhasil meluncurkan layanan internet banking dan mobile banking.

\section{Keberhasilan Pemberdayaan TI dan Prospeknya}

Pemberdayaan/pendayagunaan teknologi adalah kebutuhan yang dimiliki dan harus dipenuhi oleh semua perusahaan, baik perusahaan besar maupun kecil untuk mempunyai daya saing yang kompetitif. Untuk perusahaan kecil dibutuhkan solusi manajemen TI dengan ketentuan antara lain: (1) mempunyai kemampuan untuk mengelola aplikasi, sistem, jaringan, dan internet tanpa mengganggu roda perusahaan yang telah berjalan lancar; (2) Ada kepercayaan (accountability) terhadap semua pihak yang terlibat; (3) Ada ketangguhan dalam menghadapi perubahan yang cepat.

Untuk mendukung keberhasilan dalam pengelolaan teknologi informasi harus didukung oleh empat pilar, yaitu:

1. Sistem manajemen memberikan solusi bagi perusahaan untuk mempermudah pengorganisasian seluruh sumber $\mathrm{TI}$ yang tersebar untuk dikelola secara terpusat;

2. Storage manajemen merupakan solusi yang memungkinkan pelanggan untuk meningkatkan, mengakses, membagi, dan memproteksi aset informasinya. Pengelolaan storage menjadi penting karena keberhasilan di dalam pasar global tidak hanya berkaitan dengan kualitas produk, tetapi juga seberapa cepat pelanggan dan pemasok dapat memperoleh informasi. Storage manajemen membuat perusahaan mempunyai kesiapan untuk mengimplementasikan, mengelola, dan melindungi infrastruktur informasi untuk memasuki pasar global. Dengan revolusi web dan dinamisnya perkembangan $e$ business saat ini, ketersediaan informasi menjadi satu mission critical bagi suatu usaha untuk dapat terus bersaing dan dapat cepat menjawab kebutuhan pasar; 
3. Sistem keamanan adalah solusi keamanan yang mampu memecahkan masalah keamanan yang muncul dari e-business, dengan memberikan solusi pengelolaan keamanan yang terpusat;

4. Pervasive manajemen. Tantangan bagi $\mathrm{ClO}$ (Chief Information Officer) saat ini adalah membangun suatu sistem yang telah ada untuk memfasilitasi pengelolaan perangkat, baik yang tradisional maupun nontradisional. Pervasive manajemen merupakan suatu solusi yang dapat membangun, memberikan, dan mengelola secara cepat dan tepat kebutuhan layanan perangkat bergerak dengan semua perkembangannya.

Kondisi saat ini serta masa-masa mendatang, para analis memprediksikan bahwa pengelolaan teknologi merupakan kunci keberhasilan dalam transformasi $e$ business. Oleh karena itu jika sebuah perusahaan tidak melakukan hal tersebut akan kalah bersaing dengan para pesaingnya (kompetitornya). Untuk itu pengelolaan teknologi sudah merupakan suatu keharusan bagi setiap perusahaan untuk dapat meraih keunggulan yang kompetitif.

\section{Semakin}

konvergennya perkembangan Teknologi Informasi dan Telekomunikasi dewasa ini, telah mengakibatkan semakin beragamnya pula aneka jasa-jasa (features) fasilitas telekomunikasi yang ada, serta semakin canggihnya produk-produk teknologi informasi yang mampu mengintegrasikan semua media informasi. Di tengah globalisasi komunikasi yang semakin terpadu (global communication network) dengan semakin populernya Internet seakan telah membuat dunia semakin menciut (shrinking the world) dan semakin memudarkan batas-batas negara berikut kedaulatan dan tatanan masyarakatnya. Ironisnya, dinamika masyarakat Indonesia yang masih baru tumbuh dan berkembang sebagai masyarakat industri dan masyarakat Informasi, seolah masih tampak prematur untuk mengiringi perkembangan teknologi tersebut. Tentunya kalau hal ini dibiarkan berlarutlarut maka kita tak akan lagi mampu bersaing dengan negara-negara tetangga.

Pemanfaatan ICT dan e-Business akan semakin berkembang di Indonesia yang memiliki penduduk 220 juta jiwa lebih dan hal ini merupakan pasar yang sangat atraktif bagi para pengusaha. Mereka, tentunya, membutuhkan berbagai perangkat ICT untuk mendukung kelangsungan bisnisnya di Indonesia, seperti telepon, faksimili maupun internet. Perangkat ini bukan hanya untuk menjual dan membeli, tapi juga untuk melayani pelanggan dan melakukan kerja sama dengan mitra bisnis masing-masing Selain itu, sebagai negara kepulauan terbesar di dunia, interaksi antar penduduk yang tersebar di berbagai pulau paling efisien dengan memanfaatkan ICT. Walau perkembangannya tidak sepesat negaranegara Asia lainnya, seperti Korea Selatan dan RRCina, ICT dan e-Business di Indonesia tetap akan berkembang dan semakin mempengaruhi kehidupan personal dan bisnis. Jika dilihat sebagai pasar, tentu saja Indonesia sangat menarik. Indonesia memiliki keunggulan komparatif dalam hal jumlah penduduk. Sementara itu, sarana dan prasarana 
telekomunikasi yang ada masih jauh dari memadai. Dengan jumlah di atas 200 juta jiwa, densitas telepon saluran tetap di sini hanya berkisar antara 3-4\% dari total penduduknya. Faktor lain yang juga bisa mendorong pertumbuhan itu adalah kian banyaknya jumlah kalangan terdidik di Indonesia. Tentu saja, semakin besarnya jumlah kalangan ini akan semakin meningkatkan intensitas penggunaan ICT di Indonesia. Karenanya, Indonesia juga tidak boleh melupakan faktor pendidikan dalam konteks ini. Ini penting bila Indonesia ingin berperan sebagai pengembang dan produsen. Bukan hanya sebagai pengguna. Pemerintah dan kalangan swasta harus mendukung upaya edukasi dalam bidang ini.

\section{E. Kesimpulan.}

Pemberdayaan teknologi informasi saat sekarang ini sudah merupakan kebutuhan yang dimiliki dan harus dipenuhi oleh semua perusahaan, baik perusahaan berskala besar maupun perusahaan berskala kecil agar mempunyai daya saing yang kompetitif. Solusi manajemen TI bagi perusahaan yang berskala kecil antara lain yang penting perusahaan mempunyai kemampuan untuk mengelola aplikasi, sistem, jaringan, dan internet. Dalam perusahaan harus ada kepercayaan (accountability) terhadap semua pihak yang terlibat dan ada ketangguhan dalam menghadapi perubahan yang cepat.

Faktor penentu keberhasilan pengelolaan teknologi informasi di dalam perusahaan harus didukung paling tidak oleh empat pilar, yaitu: (1) Sistem manajemen $\mathrm{TI}$; (2) Storage manajemen $\mathrm{TI}$; (3) Sistem keamanan dari e-business, (4) dan Pervasive manajemen diharapkan akan menjadi kunci keberhasilan dalam transformasi ebusiness. Kondisi saat ini serta masamasa mendatang, para analis memprediksikan bahwa pengelolaan teknologi informasi melalui ebusiness maupun e-commerce merupakan kunci keberhasilan dalam memenangkan persaingan. Oleh karena itu jika sebuah perusahaan tidak melakukan hal tersebut akan kalah bersaing dengan para pesaingnya (kompetitornya). Untuk itu pengelolaan teknologi sudah merupakan suatu keharusan bagi setiap perusahaan untuk dapat meraih keunggulan yang kompetitif.

\section{Daftar Pustaka}

AB. Susanto, "E-Business Dipilih ?", Business.htm.

Anonim. (2003). "Strategi dan Perencanaan untuk Memulai usaha". Analysis. Selasa 29 J uli 2003.

Arrianto Mukti Wibowo dkk. (1999). Kerangka Hukum Digital Signature dalam Electronic Commerce. Fakultas Hukum UI Jakarta.

Bank Indonesia. (2004). Arsitektur Perbankan Indonesia. J akarta. 
Barcelius Ruru. (1998). "Reorientasi Pengeloloaan BUMN dalam Upaya Mencari Format Baru yang Efisien dan Modern". Makalah Seminar. Jakarta 23 Juli 1998.

Bob Julius Onggo. "Apa Itu E-PR". www.bjoconsulting. Com.

Dawam Rahardjo. (2004). "Isu-isu Kontemporer Ekonomi Pancasila". Makalah Pusat Studi Ekonomi Pancasila UGM. 6 April 2004. Yogyakarta.

Hermawan Kartajaya. (2003). "IT Tidak Pesat Tapi Berpengaruh Besar". E-BizzAsia. Vol I Nomor 11 Oktober 2003.

Julia Aryanti Widjaja. "Pendayagunaan Teknologi Untuk Keunggulan Bisnis". Media Indonesia. Jakarta.

Kottler, Philip. (1999). Manajemen Pemasaran. Terjemahan. Jakarta: Erlangga.

Ningky Munir. (2003). Logika Baru Meningkatkan Daya Saing Perusahaan. Jakarta: Lembaga Manajemen PPM.

Pusat Pengkajian Divisi Teknologi. (2003). “Membangun Sistem Kelembagaan Balitbangda Berkinerja Tinggi Dalam Rangka Meningkatkan Pembangunan Ekonomi Berbasis I ptek". Hasil Semiloka.

Stiglitz, Josep E. (2002). Globalization and Its Discontents. London: WW Norton Company.

Umar Juoro. (2003). Oligopoli dan Industrialisasi. Centre for Information and Development Studies.

Wainright Martin. E. (1991). Management Information Technology. New York: MacMillan.

Warta Ekonomi.Com. (Oktober 2002). "Pemenang E-Company Award 2002". 